\title{
OCCURRENCE (NEW RECORD) OF MANED WOLF Chrysocyon brachyurus (Illiger, 1815) (CARNIVORA, CANIDAE) IN SOUTHERN BRAZIL
}

OCORRÊNCIA (NOVO REGISTRO) DE LOBO-GUARÁ Chrysocyon brachyurus (Illiger, 1815) (CARNIVORA, CANIDAE) NO SUL DO BRASIL

\author{
Leandro Chisté Pinto ${ }^{1}$ Marcelo Maisonette Duarte ${ }^{2}$
}

\begin{abstract}
The present study presents the record of occurrence of Chrysocyon brachyurus (Illiger, 1815) in an area of wet grasslands which is adjacent to the riparian forest along Ibicui river, Rio Grande do Sul state, Brazil. The species was found through the use of camera traps and search of vestiges in pre-established transections in the area, as part of a environmental monitoring program of a forestation project.
\end{abstract}

Keywords: Chrysocyon brachyurus; maned wolf; Pampa; forestation projects.

\section{RESUMO}

No presente estudo é apresentado o registro da ocorrência de Chrysocyon brachyurus (Illiger 1815) em uma área de campo úmido adjacente a faixa de mata ciliar do rio Ibicuí, estado do Rio Grande do Sul, Brasil. A espécie foi encontrada através do uso de armadilhas fotográficas e da procura de vestígios em transecções pré-estabelecidas na área, como parte de um programa de monitoramento ambiental de um projeto silvicultural.

Palavras-chave: Chrysocyon brachyurus; lobo-guará; Pampa; silvicultura.

\section{INTRODUCTION}

In the past, maned wolf (Chrysocyon brachyurus, Illiger, 1815) was widely distributed in areas of open vegetation of 'Cerrado', 'Chaco' and 'Pampa' (DIETZ, 1984; RODDEN et al., 2004; CHIARELLO et al., 2008). Presently, its geographical distribution has suffered with a dramatic reduction in those three biomes, particularly due to the intense fragmentation, as natural areas have been replaced by anthropic landscapes.

The great majority of records and ecological studies in Brazil have concentrated in the 'Cerrado' region, which is the core zone of distribution of this species (DIETZ, 1984; SILVEIRA et al.,
2009), and are mainly focused on the diet of $C$. brachyurus (JÁCOMO et al., 2009). In the Pampa region of southern Brazil and Uruguay scientific records have been scarce (QUEIROLO, 2009), and there has been a lack of precise information about its occurrence for more than 30 years in Brazil (INDRUSIAK and EIZIRIK, 2003) and for more than 20 years in Uruguay (MONES and OLAZARRI, 1990; COSSE et al., 2005).

This species was considered rare in Rio Grande do Sul state, southern Brazil, by Ihering (1927). Silva (1984) has reported that the species, even being on the verge of extinction in this State at that time, was still indiscriminately hunted. The distribution in this state nowadays is quite residual, and there is unreliable confirmation about its

1. Biólogo, Consultor Ambiental, Diretor da Sustenta Consultoria Ambiental, Av. Sílvio Sanson, 1099, Sala 1101, CEP 99200-00, Guaporé (RS). sustenta@sustentameioambiente.com.br

2. Biólogo, Dr., Professor Adjunto da Universidade Estadual do Rio Grande do Sul, Unidade de São Francisco de Paula, Rua Assis Brasil, 842, CEP 95400-000, São Francisco de Paula (RS). maisonette.duarte@gmail.com / marcelo-duarte@uergs.edu.br

Recebido para publicação em 28/03/2011 e aceito em 13/09/2011 
existence only at the border with Uruguay, in the 'Pampa' biome, and in 'Campos de Cima da Serra' region (CHIARELLO et al., 2008; QUEIROLO, 2009). Currently, the species is considered endangered in Brazil and it has been included in the category of vulnerable one (MACHADO et al., 2008). In Rio Grande do Sul state, its status is critically endangered (FONTANA et al., 2003). In Uruguay this species is also considered endangered (GEO URUGUAY, 2008).

This work presents a new record of $C$. brachyurus, obtained during the environmental monitoring of medium and large-sized mammals of a forestation project that has been developed in the southern of Rio Grande do Sul state.

\section{MATERIAL AND METHODS}

\section{Area of study}

The record was obtained during monitoring of medium and large-sized mammals in a property of about 1,580 ha where the main activity is silviculture of Eucalyptus spp. (Mytarceae) associated with cattle raising. The site is situated about five kilometers from the urban area of Cacequi municipality, in RS state, at the bank of Ibicui river (Fig. 1). The regional landscape is formed basically by relief from 60 to 120 meter (MSL). 'Pampa' biome is characterized by the prevalence of grasslands, presenting gallery forests of shrubby aspect along water courses. These forests become more developed along large rivers, such as Ibicui river. The main anthropic activities in that region are cattle raising, and rice and watermelon crops. Several silviculture projects have been implemented in the recent years.

\section{Methodology}

The study was carried out from $1^{\text {st }}$ to $7^{\text {th }}$ July, 2009. Three methodologies have been used to gather information about mammal's presence: a) Transections for search of direct observations or indirect vestiges (footprints, odors, carcasses, feces, and marks on the vegetation) covering

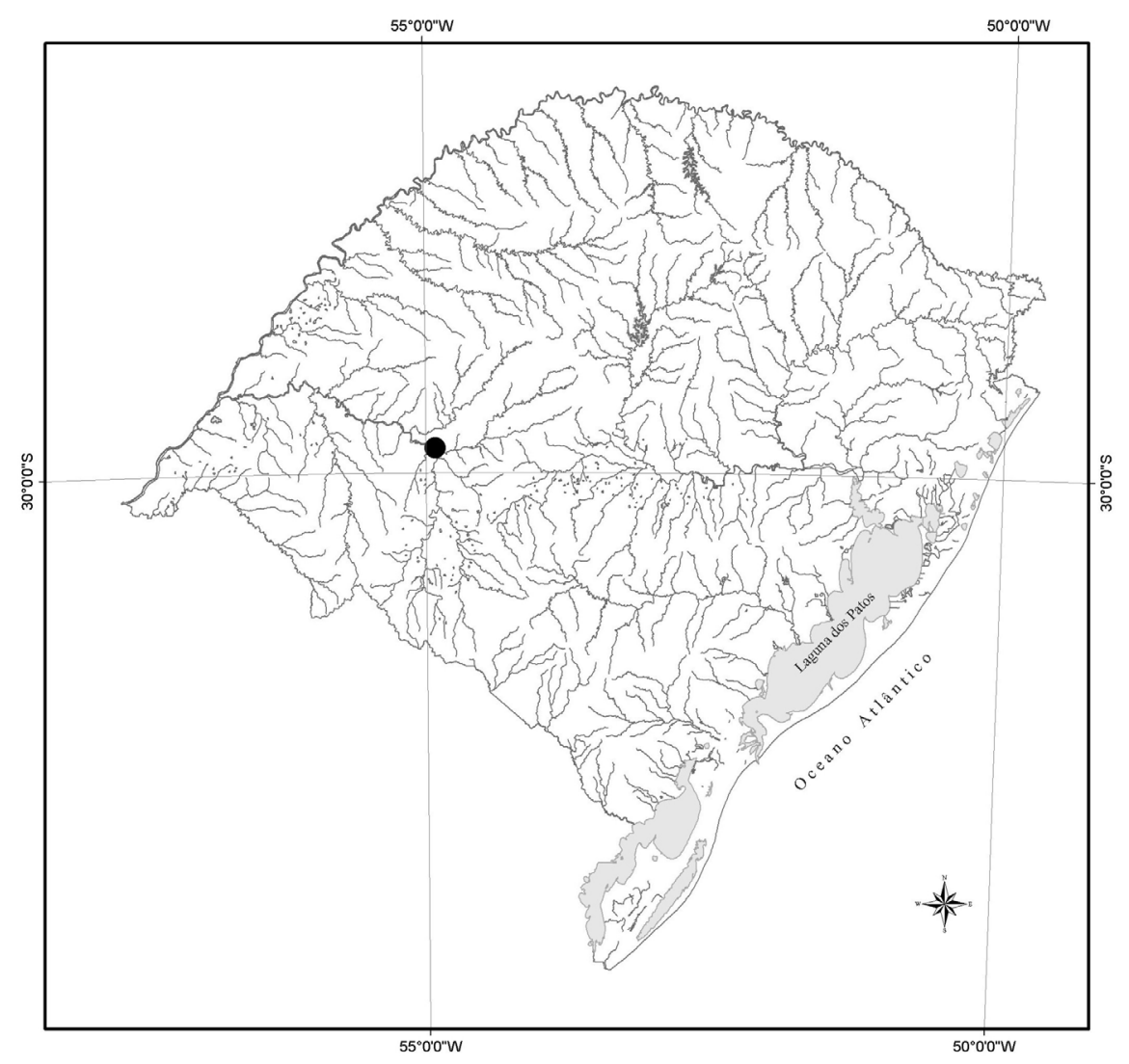

FIGURE 1: Geographical location of the study area in Cacequi, Rio Grande do Sul state, Brazil. (UTM 21J 705532/6697171; datum SAD69).

FIGURA 1: Localização geográfica da área de estudo em Cacequi, estado do Rio Grande do Sul, Brasil. (UTM 21J 705532/6697171; datum SAD69). 
around 10 kilometers. Sweeps were carried out in different environments, seeking for a proportional equity of efforts/hours in the different sampled areas. The searches occurred at different day hours, and all the mammals visualized or heard during the field work were recorded; b) Transections for nocturnal visualization: approximately $35 \mathrm{Km}$ of roads were covered in the study area as well as in its surroundings with the use of an automobile at approximately $20 \mathrm{Km} \cdot \mathrm{h}^{-1}$, attempting to records the mammals which have typical nocturnal activity. In order to facilitate visualization, a 1,500,000 longrange spot lamp was used. The searches were carried out between $6.45 \mathrm{pm}$ and $11.30 \mathrm{pm}$; c) Camera traps: nine camera traps were assembled in different environments (spots of grasslands, native riparian forest and swamps) of the study area for 24 hours, totalizing an effort of 54 traps/night. The traps were distributed according to spots where vestiges had been previously identified in 2007, during four campaigns carried out for a previous study of environmental impact (EIA) of the silvopasture enterprise mentioned.

\section{RESULTS AND DISCUSSION}

The results have shown the occurrence of 17 species of mammals belonging to 13 families (Table 1). For diurnal observations based on transections it was found 16 species and one

TABLE 1: Inventory of mammal species found during monitoring campaign in riverbank forest along Ibicui River, in Cacequi, RS state, July 2009. Abbreviations: FC, feces; CT, camera trap; FP, footprints; V, view; SH, shelter/burrow.

TABELA 1: Inventário das espécies de mamíferos encontradas durante campanha de monitoramento em mata ciliar do rio Ibicuí, em Cacequi, RS, julho de 2009. Abreviaturas: FC, fezes; CT, armadilhas fotográficas; FP, pegadas; V, visualização; SH, tocas/buracos.

\begin{tabular}{|c|c|}
\hline Family/Sub-family/Species & Type of record found \\
\hline \multicolumn{2}{|l|}{ Didelphidae } \\
\hline Didelphis albiventris Lund, 1840 & $\mathrm{CT}, \mathrm{FT}$ \\
\hline \multicolumn{2}{|l|}{ Dasypodidae } \\
\hline Dasypus novemcinctus Linnaeus, 1758 & FP \\
\hline Euphractus sexcinctus (Linnaeus, 1758) & $\mathrm{CT}, \mathrm{FT}$ \\
\hline \multicolumn{2}{|l|}{ Atelidae } \\
\hline Alouatta caraya (Humboldt, 1812) & $\mathrm{V}$ \\
\hline \multicolumn{2}{|l|}{ Leporidae } \\
\hline Lepus sp. & FP \\
\hline \multicolumn{2}{|l|}{ Felidae } \\
\hline Leopardus geoffroyi (D’Orbigny \& Gervais, 1844) & CT, FP \\
\hline \multicolumn{2}{|l|}{ Canidae } \\
\hline Cerdocyon thous (Linnaeus, 1766) & $\mathrm{CT}, \mathrm{FP}$ \\
\hline Lycalopex gymnocercus (G. Fisher, 1814) & $\mathrm{CT}, \mathrm{FP}, \mathrm{V}$ \\
\hline Chrysocyon brachyurus (Illiger, 1815) & FC, CT, FP \\
\hline \multicolumn{2}{|l|}{ Mustelidae } \\
\hline Lontra longicaudis (Olfers, 1818) & FP \\
\hline \multicolumn{2}{|l|}{ Mephitidae } \\
\hline Conepatus chinga (Molina, 1782) & $\mathrm{CT}, \mathrm{V}$ \\
\hline \multicolumn{2}{|l|}{ Procyonidae } \\
\hline Procyon cancrivorus (G. [Baron] Cuvier, 1789) & $\mathrm{CT}, \mathrm{FP}, \mathrm{V}$ \\
\hline \multicolumn{2}{|l|}{ Cervidae } \\
\hline Mazama guazoubira (Fischer, 1814) & FP \\
\hline \multicolumn{2}{|l|}{ Caviidae } \\
\hline Cavia sp. & FP \\
\hline \multicolumn{2}{|l|}{ Sub-family Hydrochaerinae } \\
\hline Hydrochoerus hydrochaeris (Linnaeus, 1766) & FP \\
\hline \multicolumn{2}{|l|}{ Ctenomyidae } \\
\hline Ctenomys torquatus Lichtenstein, 1830 & $\mathrm{SH}$ \\
\hline \multicolumn{2}{|l|}{ Myocastoridae } \\
\hline Myocastor coypus (Molina, 1782) & $\mathrm{CT}, \mathrm{V}$ \\
\hline
\end{tabular}



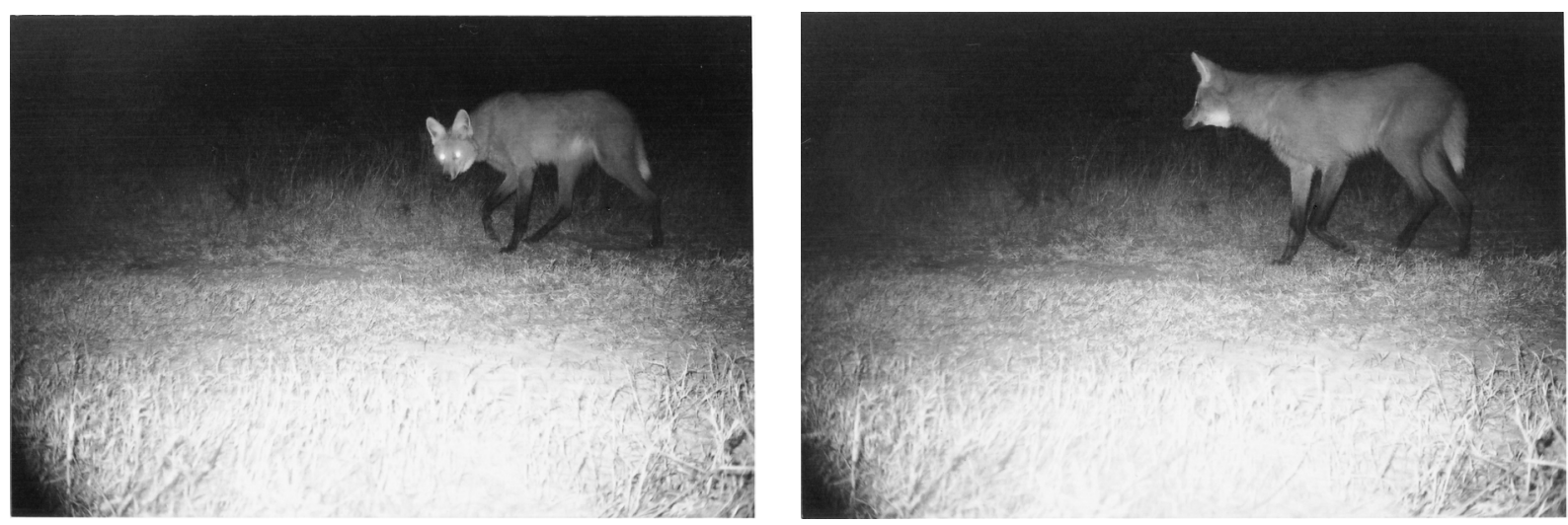

FIGURE 2: Chrysocyon brachyurus (Illiger, 1815) recorded by camera traps. Cacequi, RS state, July 2009. (UTM (SAD69) 21J 705532/6697171).

FIGURA 2: Chrysocyon brachyurus (Illiger, 1815) registrado através de armadilhas fotográficas. Cacequi, RS, julho, 2009. (UTM (SAD69) 21J 705532/6697171).

occurrence of feces of $C$. brachyurus containing hairs of Myocastor coypus (Molina, 1782), besides a large amount of non-identified vegetal material. In relation to $C$. brachyurus, we have also found tracks (footprints) in two spots in the study area. The success of capture was 1.6 species per kilometer covered. Through the night visualization transections, it was recorded two species of mammals. The index of animals observed was 0.14 specimens per kilometer covered, and there was no record of $C$. brachyurus in those night transsections. Considering camera traps, we have obtained 62 photographic records of nine mammal species. The total capture success was 1.19 specimens per trap/night. Six photographic records were obtained from C. brachyurus (Fig. 2).

The records presented here is an indication that the species can occasionally be found in the Brazilian Pampa, despite several years of fragmentation of their natural habitat, particularly due to the conversion of natural habitat into annual crops, forestation projects and extensive cattle raising, often with soil exhaustion, as well as to the persecution of this species by men, threats that are also usual in other areas of the geographic distribution of this species (DIETZ, 1984; SALIM et al., 2007; CHIARELLO et al., 2008).

It is worth noticing that, due to the absence of conservation units in that region (BRANDÃO et al., 2007; DUARTE, 2008), the survival of this species (and many others) has probably occurred in small natural fragments into particular areas, such as the one here considered, which has recovered its riparian forest along Ibicui river since the implantation of the silviculture project five years ago, as well as adjacent wet grasslands and swamps. Furthermore, some studies also suggest that forest plantations can catalyze the natural regeneration in their understory and, thus, contribute to biodiversity conservation (VIANI et al., 2010).

The maned wolf has a high capacity of adaptation to environments disturbed by man (MASSARA, 2009), but certainly the areas of permanent preservation of these plantations are not sufficient to maintain populations of maned wolf, an omnivorous species with a very broad and seasonal diet (BUENO et al., 2003; AMBONI, 2007; JÁCOMO et al., 2009; MASSARA, 2009), requiring a home-range from about 30 to $140 \mathrm{Km}^{2}$ (MANTOVANI, 2001; JÁCOMO et al. 2009).

Food items that are typical of this species, such as rodents and tinamids (SILVEIRA et al., 1997; BUENO and MOTTA-JR, 2004; JÁCOMO et al., 2004; RODRIGUES et al., 2007), have found shelter in such areas, as mesic environments like these are fundamental to the maintenance of regional biodiversity (BENCKE, 2009). The populations of spotted Nothura (Nothura maculosa, Temminck, 1815) and red-winged tinamou (Rhynchotus rufescens, Temminck, 1815) seem to have increased both in early stage Eucalyptus plantations and in permanent preservation areas associated to well-managed forestation projects (DUARTE et al., no prelo), which may act as "ecological corridors" or "biodiversity hotspots" (see CAMUS et al., 2006; VIANI et al., 2010). 
There are many issues to be approached concerning the basic biology and ecology of $C$. brachyurus. The home-range and feeding behavior, as well as studies considering the species genetic variability (e.g. MATTOS, 2003; COSSE et al., 2005; SALIM et al., 2007) would be fundamental in more consistent approaches of conservation actions (see COSTA et al., 2005) in Pampa biome. Population studies outside conservation units for example, where human pressure is higher, are quite scarce in Brazil (e.g. MASSARA, 2009; MAY-JR et al., 2009), and most fragments that may support the maintenance of regional biodiversity are located in private lands, in which there is urgent need for conservation strategies for all species (e.g. BAUNDRY, 1989; SAUNDERS et al., 1991; DUARTE, 2004; SILVEIRA et al., 2009).

Considering that the record location (UTM 21J 705532/6697171; datum SAD69) is near the urban area of Cacequi, RS state, the possibility of interrelation with domestic animals, mainly with other canids (e.g. MAY-JR et al., 2009), as well as the proximity to human presence (e.g. DIETZ, 1984; SILVA and TALAMONI, 2003; MASSARA, 2009), could threat $C$. brachyurus in that region, by exposing them to diseases like canine distemper virus and parvovirus (MAIA et al., 1999) or either to hunters and fishers that illegally explore the banks of Ibicui, Cacequi and Santa Maria rivers. The present record extends the small occurrence area of $C$. brachyurus defined in Rodden et al. (2004), a little to the north towards the Pampa biome in Brazil. This area, which can be defined as the region of Santa Maria river basin, in the municipalities of Dom Pedrito, Santana do Livramento and Rosário do Sul, is directly linked to the area of the present record through scarce gallery forests and mesic environments associated to pastures, crops and forestation projects along Santa Maria river, near Santa Maria's mouth in Ibicui river.

\section{ACKNOWLEDGEMENTS}

We are grateful to 'Granflor Gestão de Empreendimentos Florestais Ltda.', for the logistic support of this study.

\section{REFERENCES}

AMBONI, M. P. M. Dieta, disponibilidade alimentar e padrão de movimentação de loboguará, Chrysocyon brachyurus, no Parque
Nacional da Serra da Canastra, MG. 2007. 108 f. Dissertação (Mestrado)-Universidade Federal de Minas Gerais, Belo Horizonte, 2007.

BAUNDRY, J. Interactions between agricultural and ecological systems at the landscape level. Agriculture, Ecosystems ans Environment, v. 27, p. 119-130. 1989.

BENCKE, G. A.. Diversidade e conservação da fauna dos campos do sul do Brasil. In: PILLAR, V. de P. et al. (Eds.) Campos Sulinos: conservação e usos sustentável da biodiversidade. Brasília, MMA. 2009, p. 101-121. Cap. 7.

BRANDÃO, T.; TREVISAN, R.; BOTH, R. Unidades de Conservação e os campos do Rio Grande do Sul. Revista Brasileira de Biociências, v. 5, n. 1, p. 843-845. 2007.

BUENO, A. de A.; BELENTANI, S.C. da .S.; MOTTA-JR, J. C. Feeding ecology of the maned wolf, Chysocyon brachyurus (Illiger, 1815) (Mammalia, Canidae), in the Ecological Station of Itirapina, São Paulo State, Brazil. Biota Neotropica, v. 2, n. 2, p. 2003.

BUENO, A. de A.; MOTTA-JR., J. C. Food habits of two syntopic canids, the maned wolf (Chrysocyon brachyurus) and the crab-eating fox (Cerdocyon thous), in southeastern Brazil. Revista Chilena de Historia Natural, v. 77, p. 5-14. 2004. CAMUS, J.-M. et al. Planted forests and biodiversity. Journal of Forestry, v. 104, n.2, p. 65-77. 2006.

CHIARELlO, A. G. et al. Mamíferos ameaçados de extinção no Brasil. p. 681-874. In: MACHADO, A. B. M.; DRUMMOND, G. M.; PAGLIA, A. P. (eds.). Livro vermelho da fauna ameaçada de extinção. v. II. Brasília. MMA, 2008. 907 p. (Biodiversidade, 19).

COSSE, M. et al. E. Aguará guazú (Chrysocyon brachyurus) em el Uruguay (Mammalia: Carnivora: Canidae). In: JORNADA ZOOLOGIA URUGUAY, 8., 2005, Montevidéu. Anais... Motevideu, 2005. p.55.

COSTA, L. P. et al. Conservação de mamíferos no Brasil. Megadiversidade, v. 1, n. 1, p. 103-112. 2005.

DIETZ, J. M. Ecology and social organization of the maned wolf. Smithsonian Contributions to Zoology, v. 392, p. 1-51. 1984.

DUARTE, M. M. Abundância de microartrópodes do solo em fragmentos de mata com araucária no sul do Brasil. Iheringia, Serie Zoologia, v. 94, n. 2, p. 163-169. 2004.

DUARTE, M. M. Áreas naturais protegidas no Rio 
Grande do Sul. Revista Colóquio, v. 6, n. 1-2, p. 87-93. 2008.

FONTANA, C. S.; BENCKE, G. A.; REIS, R. E. (eds.). Livro vermelho da fauna ameaçada de extinção no Rio Grande do Sul. Porto Alegre, Ed. PUCRS. 2003.

GEO URUGUAY. Informe del estado del ambiente. Programa de Naciones Unidas para el Medio Ambiente (PNUMA), Centro Latino Americano de Ecologia Social (CLAES), Dirección Nacional del Médio Ambiente (DINAMA). 2008, $350 \mathrm{p}$.

IHERING, H. von. Os mamíferos do Rio Grande do Sul. Rev. do Museu e Archivo Publico do Rio Grande do Sul, v. 19, p. 41-77. 1927.

INDRUSIAK, C.; EIZIRIK, E. Carnívoros. In: FONTANA, C. S.; BENCKE, G. A.; REIS, R. E. (eds.). Livro vermelho da fauna ameaçada de extinção no Rio Grande do Sul. Porto Alegre, Ed. PUCRS. 2003, p. 507-534.

JÁCOMO, A. T. A., SILVEIRA, L.; DINIZ-FILHO, J. A. F. Niche separation between the maned Wolf (Chrysocyon brachyurus), the crab-eating Fox (Dusicyon thous) and the hoary Fox (Dusicyon vetulus) in central Brazil. Journal of Zoology, London, v. 262, p. 99-106. 2004.

JÁCOMO, A. T. et al. Home range and spatial organization of maned wolves in the brazilian grasslands. Journal of Mammalogy, v. 90, n. 1, p. 150-157. 2009.

MACHADO, A. B. M.; DRUMMOND, G. M.; PAGLIA, A. P. (eds.). Livro vermelho da fauna ameaçada de extinção. Vol. II. Brasília. MMA, 2008, 907 p. (Biodiversidade 19).

MAIA, O. B. et al. Avaliação pós-vacinal de Lobosguarás Chrysocyon brachyurus (Illiger, 1811) contra os vírus da cinomose e parvirose canina. Arq. Bras. Med. Vet. Zootec., v. 51, n. 5, p. 415-490, 1999. MANTOVANI, J. E. Telemetria convencional e via satélite na determinação da área de vida de três espécies de carnívoros na região nordeste do estado de São Paulo. 2001, 118 f. Tese de Doutorado. Universidade Federal de São Carlos, 2001.

MASSARA, R. L. Dieta, uso do hábitat e endoparasitas fecais do lobo-guará na Serra da Calçada, região metropolitana de Belo Horizonte, Minas Gerais. 2009. 68 f. Dissertação de Mestrado. Pontifícia Universidade Católica de Minas Gerais, Belo Horizonte, 2009.

MATTOS, P. S. R. de. Epidemiologia e genética populacional de lobos guarás,
Chrysocyon brachyurus (Illiger, 1815) (Carnivora, Canidae) no nordeste do estado de São Paulo. 2003. 85 f. Tese de Doutorado. Universidade Federal de São Carlos, São Carlos, 2003.

MAY-JR., J. A. et al. Hematology and blood chemistry parameters differ in free-ranging maned wolves (Chrysocyon brachyurus) living in the Serra da Canastra National Park versus adjacent farmlands, Brazil. Journal of Wildlife Diseases, v. 45, n. 1, p. 81-90. 2009.

QUEIROLO, D. Diversidade e padrões de distribuição de mamíferos dos Pampas do Uruguai e Brasil. 2009. 333 f. Tese de Doutorado, Instituto de Biociências da Universidade de São Paulo, 2009.

RODDEN,M.;RODRIGUES, F.;BESTELMEYER, S. Maned Wolf (Chrysocyon brachyurus), p. 3844. In: SILLERO-ZUBIRI, C.; HOFFMANN, M.; MACDONALD, D. W. (Eds.). Canids: foxes, wolves, jackals and dogs. Status survey and conservation action plan. Gland, Switzerland and Cambridge, UK, IUCN/SSC Canid Specialist Group. 2004, 430 p.

RODRIGUES, F. H. G. et al. Feeding habits of the maned wolf (Chrysocyon brachyurus) in the brazilian Cerrado. Mastozoologia Neotropical, v. 14, n. 1, p. 37-51. 2007.

SALIM, D. C. et al. Genetic variability in maned Wolf based on heterologous short-tandem repeat markers from domestig dog. Genetics and Molecular Research, v. 6, n. 2, p. 348-357. 2007.

SAUNDERS, D. A.; HOBBS, R.J.; MARGULES, C.R. Biological consequences of ecosystem fragmentation: a review. Conservation Biology, v. 5, n. 1, p. 18-52. 1991.

SILVA, F. Mamíferos do Rio Grande do Sul. Porto Alegre, Fundação Zoobotânica do Rio Grande do Sul. 1984.

SILVA, J. A.; TALAMONI, S. A. Diet adjustments of maned wolves, Chrysocyon brachyurus (Illiger) (Mammalia, Canidae), subjected to supplemental feeding in a private natural reserve, southeastern Brazil. Revista Brasileira de Zoologia, v. 20, n. 2, p. 339-345. 2003.

SILVEIRA, L. et al. Hunting association between the aplomado falcon (Falco femoralis) and the maned wolf (Chrysocyon brachyurus) in Emas Natinal Park, central Brazil. The Condor, v. 99, p. 201-202. 1997.

SILVEIRA, L. et al. Maned Wolf density in a central braziliand grassland reserve. The Journal 
of Wildlife Management, v. 73, n. 1, p. 68-71. de. A regeneração natural sob plantações florestais: 2009. desertos verdes ou redutos de biodiersidade?

VIANI, R. A. G.; DURIGAN, G.; MELO, A. C. G Ciência Florestal, v. 20, n. 3, p. 533-552. 